\title{
Animal Components of the Diet of the Striped Field Mouse under Urban Conditions
}

\author{
Joanna BABIŃSKA-WERKA \& Henryk GARBARCZYK
}

\begin{abstract}
Babińska-Werka J. \& Garbarczyk H., 1981: Animal components of the diet of the striped field mouse under urban conditions. Acta theriol., 26, 18: $301-318$ [With 6 Tables \& 3 Figs.].

Examination was made of the animal components of the diet of the striped field mouse, Apodemus agrarius (Pallas, 1771), living under suburban conditions (Białołęka Dworska) and in urban green areas of Warsaw (Orthodox Cemetery and Eazienki Park). The frequency of consumption of animal components is higher, while at the same time its volume in the stomachs is lower in urban mice as compared with suburban ones. Field mice consumed chiefly invertebrates, among which Insecta predominated, and to a lesser degree Aranea and Chilopoda. Invertebrates belonging to single taxonomic group predominated in the diet of urban mice (in the Orthodox Cemetery Diptera larvae, in Eazienki Park - larvae of Hymenoptera Symphyta and Lepidoptera).

Dept. of Wildlife Manage., Warsaw Agric. Univ., Rakowiecka 26/30, 02-528 Warszawa (J.B.-W.), and Inst. Zool. Polish Acad. Sci., Wilcza 64, 00-679 Warszawa (H.G.)].
\end{abstract}

\section{INTRODUCTION}

Animal component are of great importance in the diet of many rodents, since they increase the latter's capacity for survival (Landry, 1970). There are, however, few data on the amount and composition of this kind of food in the diet of Apodemus agrarius, this problem having been analyzed in detail only by Sviridenko (1944) and Holišová (1967). These authors' studies were carried out on populations living under natural conditions (in an agricultural region). The purpose of the present study was thus to define the animal components of the food consumed by field mice living in urbanized areas.

The role of Apodemus agrarius as predators in an ecosystem so specific as an urbicenosis is also discussed. For this purpose the rodents' prey was segregated according to their appurtenance to different trophic levels, and the place in which the mice live was also taken into account. An attempt was also made at estimating the relation between the amount of the given type of prey consumed and the numbers of such prey, taking as a basis unpublished quantitative data from the Institute of Zoology, Polish Academy of Sciences, obtained during the studies on invertebrate fauna carried out in the same years at Białołęka and in Łazienki Park. 


\section{STUDY AREA, MATERIAL AND METHODS}

The studies were carried out in two urban green areas in Warsaw and in suburbium. Łazienki Park, situated in the centre of the city, is a typical old urban park in which the vegetation is similar, from both species composition and structural aspects, to the association characteristic of Tilio-Carpinetum. The Orthodox Cemetery has a similar composition of vegetation, a slightly smaller green area than Eazienki Park, and is situated at a distance of approximately $3 \mathrm{~km}$ from the city centre. It is less frequented by humans than the Eazienki Park. Both the urban green areas studied were subject to the effects of a whole group of factors (pollution, noise, frequentation by humans etc.) defined by the general term of urban pressure. The suburban study area, including a Tilio-Carpinetum and a Circaeo-Alnetum assoçiation, was situated at Białołęka Dworska, at a distance of approximately $20 \mathrm{~km}$ from the city centre. A more detailed description of these areas is given in the paper by Babińska-Werka (1981).

Three series of trappings were made from 1977-1979: spring (April-June), autumn (September-October) and winter (January-March). The mice were caught in snap-traps, weighed, their sex and reproductive condition defined, and their stomachs excised. A total of 187 field mice from all the study areas were analyzed (Table 1).

Table 1

Frequency of occurrence of animal food in the stomachs of Apodemus agrarius. $\mathrm{n}$ - number of stomachs; $\%$ - percentage of stomachs containing animal food.

\begin{tabular}{|c|c|c|c|c|c|c|c|}
\hline \multirow[t]{2}{*}{ Sex } & \multirow[b]{2}{*}{ Age } & \multicolumn{2}{|c|}{ Białołęka } & \multicolumn{2}{|c|}{$\begin{array}{l}\text { Orthodox } \\
\text { Cemetery }\end{array}$} & \multicolumn{2}{|c|}{$\begin{array}{l}\text { Eazienki } \\
\text { Park }\end{array}$} \\
\hline & & $\mathrm{n}$ & $\%$ & $\mathrm{n}$ & $\%$ & $\mathrm{n}$ & $\%$ \\
\hline Females & $\begin{array}{l}\text { juv }^{1} \\
\text { ad }\end{array}$ & $\begin{array}{l}15 \\
14\end{array}$ & $\begin{array}{l}80.0^{8} \\
62.3^{8}\end{array}$ & $\begin{array}{r}8 \\
33\end{array}$ & $\begin{array}{l}62.5^{4} \\
81.8^{4}\end{array}$ & $\begin{array}{r}6 \\
13\end{array}$ & $\begin{array}{l}83.3 \\
84.6\end{array}$ \\
\hline Males & $\begin{array}{l}\text { juv } \\
\text { ad }\end{array}$ & $\begin{array}{l}16 \\
21\end{array}$ & $\begin{array}{l}75.0^{2} \\
66.7^{2}\end{array}$ & $\begin{array}{r}6 \\
31\end{array}$ & $\begin{array}{l}66.7^{5} \\
93.5^{5}\end{array}$ & $\begin{array}{r}5 \\
19\end{array}$ & $\begin{array}{l}80.0 \\
84.2\end{array}$ \\
\hline Total & $n(\%)$ & 66 & (71.2) & 78 & (83.3) & 43 & (83.7) \\
\hline
\end{tabular}

1 juv. - body wt. $<17$ g, ad. - body wt. $>17$ g;

2 Differences on the verge of significance (Student $t$ test, $0.05<p<0.1$ );

${ }^{8},{ }^{4}, 5$ Differences statistically significant (Student $t$ test, $p \leqslant 0.05$ ) when compared in pairs 22,33 etc.

The diet of these mice was examined using a modified version of Holišova's method $(1966,1971)$. Stomach contents were mixed, diluted with water and inspected under a microscope with magnification $5 \times 40$, analyzing 10 separate and not overlapping fields of vision. In order to calculate the percentage of animal food in the whole of the stomach contents, a grid was placed in the microscope eyepiece, dividing the field of vision into 100 smaller fields. The measure of volume was the percentage of the field vision occupied by animal food.

The whole of the stomach contents were examined under a binocular in order to identify the animal remains. All the animal elements were picked out and microscopic reference slide made from them.

This material was next identified using a stereoscopic microscope with magnification up to $100 \times$. In the majortiy of cases the animal food was reduced to 
very small particles, and only exceptionally were whole individuals of the invertebrates consumed, or larger fragments of hard chitinous integument, preserved (Fig. 1). Consequently identification of material was usually possible only to higher taxonomic units, such as family or order, and sometimes even to class or type only. A total of 47 taxons of different rank were distinguished (Table 2).

The following indexes were used in analysis of this material: (1) relative frequency $(\% \mathrm{f})$ - percentage of stomachs containing the given type of food in the total number of stomachs; (2) volume - percentage of volume of animal
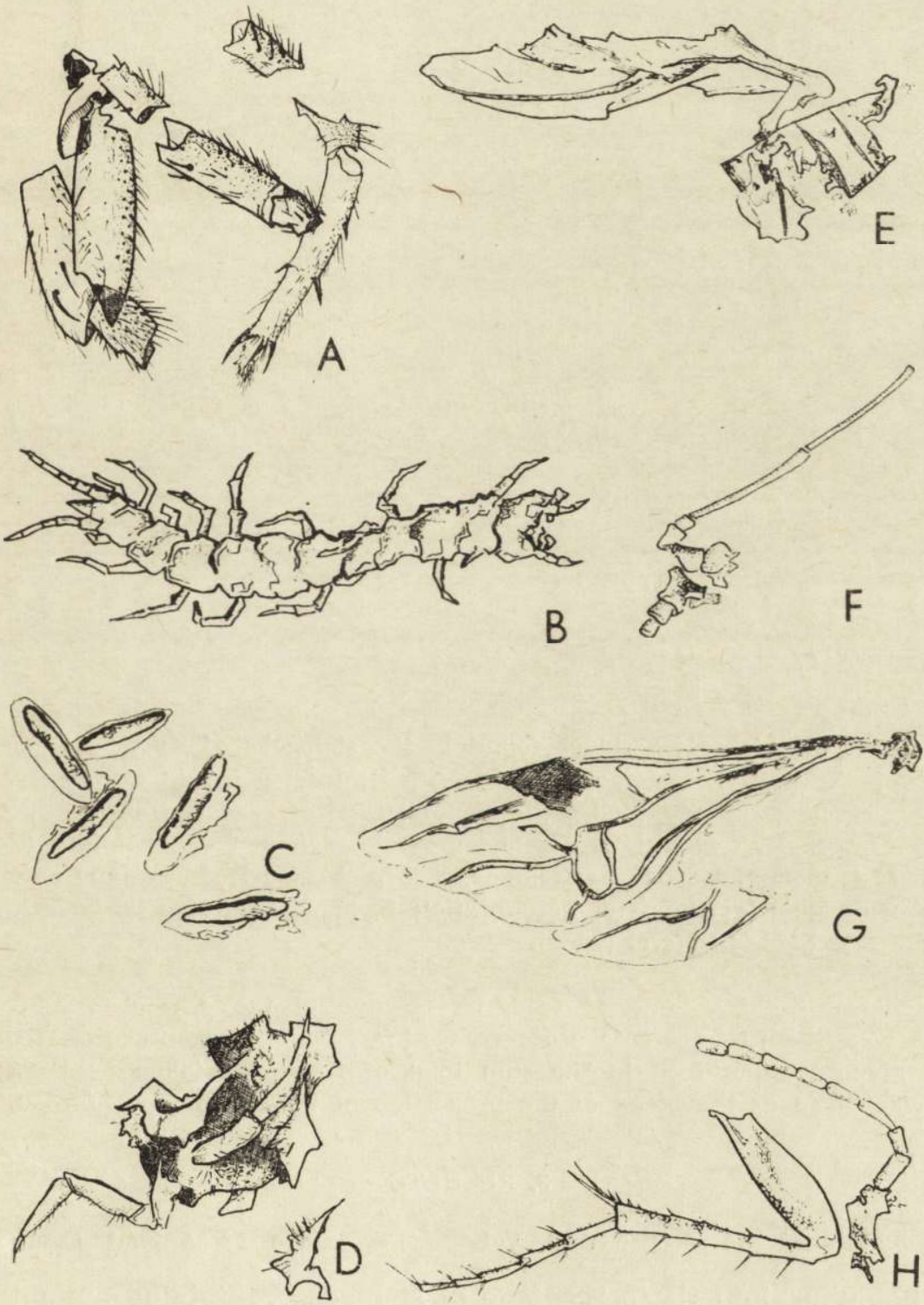

Fig. 1. For explanation see the next page. 

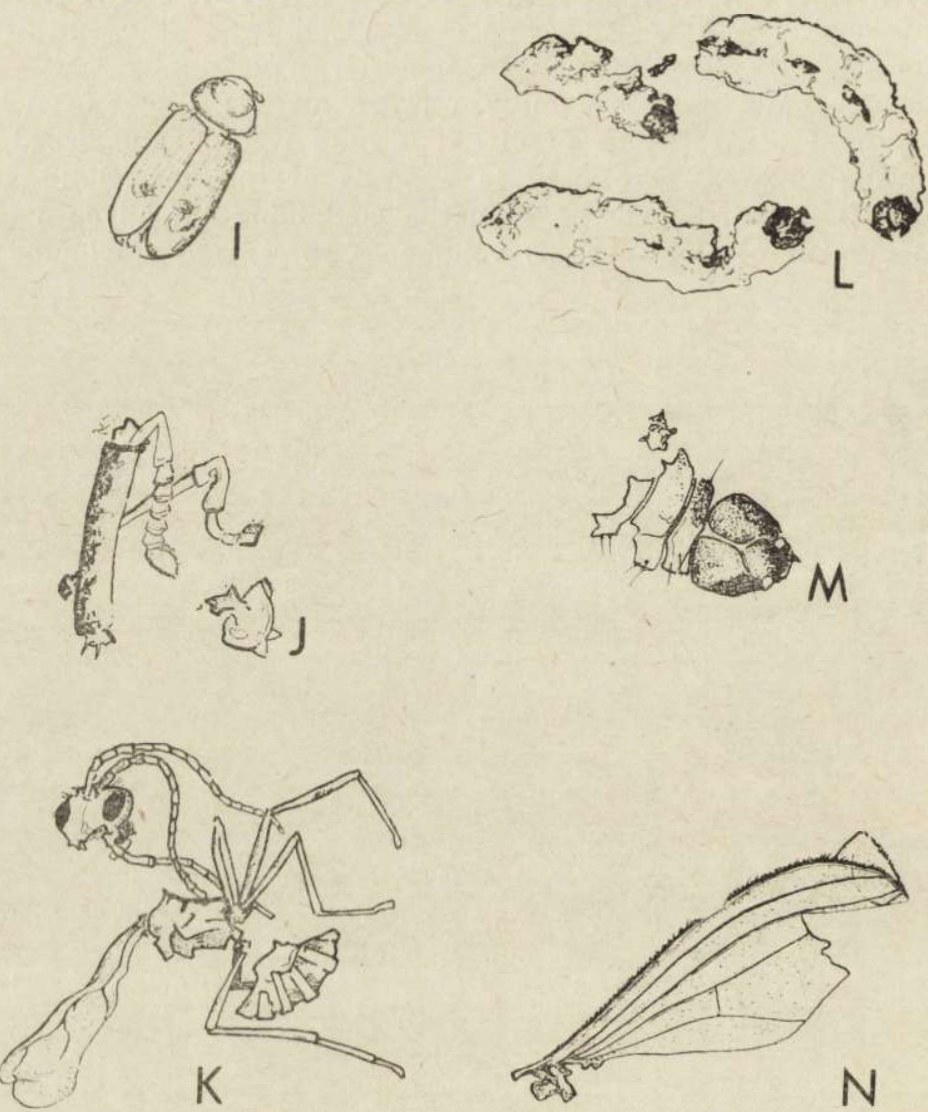

Fig. 1. Some invertebrate residues found in the stomachs of Apodemus agrarius. A - Aranea (legs); B - Lithobidae (Chilopoda); Insecta indet.: C - eggs, D larva, E - imago; F - Aphidodea (Homoptera) (part of head and antenna); Amara sp. (Carabidae): G - wing, $\mathrm{H}$ - leg and part of antenna; I - Anobiidae (Coleoptera); J - Anthonomus sp. (Curculionidae, Coleoptera) (part of head and antennae); $\mathrm{K}$ - Aphidiidae (Hymenoptera, Terebrantia); L, M - Sciaridae larvae (Diptera); $\mathrm{N}$ - Dolichopodidae (Diptera) (wing).

components in total volume of food, irrespective of the degree to which the stomach was filled; (3) percentage occurrence $[(f / \Sigma f) 100]$ - percentage of frequency of the given type of food in the sum total of frequency taken as $100 \%$; this index was taken as the index of the proportion of the given type of food.

\section{RESULTS}

\subsection{Frequency of Occurrence and Volume Percentage of Animal Components}

In the suburbium the percentage of stomachs containing animal food (out of the total number of stomachs) was $71.2 \%$, and was smaller than 
Table 2

Frequency of different taxonomic groups of animals in the stomachs of Apodemus agrarius

\begin{tabular}{|c|c|c|c|}
\hline Taxon & Białołęka & $\begin{array}{l}\text { Orthodox } \\
\text { Cemetery }\end{array}$ & $\begin{array}{l}\text { Łazienki } \\
\text { Park }\end{array}$ \\
\hline Vermes & 2.1 & - & - \\
\hline Lumbricidae & - & 1.5 & - \\
\hline Mollusca & 2.1 & 1.5 & 2.8 \\
\hline Acarina, Oribatei & - & 1.5 & \\
\hline Aranea indet. & 12.8 & 12.3 & 2.8 \\
\hline Erigonidae: Diplocephalus cristatus & - & 1.5 & - \\
\hline Chilopoda: Lithobidae & 8.5 & 3.1 & 一 \\
\hline Geophilidae: Geophilus sp. & - & 1.5 & $=$ \\
\hline Insecta indet. eggs & $\overline{0}$ & - & 5.6 \\
\hline Insecta indet. larvae & 8.5 & 1.5 & 2.8 \\
\hline Insecta indet. imagines & 29.8 & 26.1 & 22.2 \\
\hline $\begin{array}{l}\text { Caterpillars indet. (Lepidoptera, } \\
\text { Hymenoptera Symphyta) }\end{array}$ & 2.1 & 7.7 & 33.3 \\
\hline Blattodea: Blattidae & - & 1.5 & - \\
\hline Orthoptera indet. & - & 3.1 & - \\
\hline Hemiptera indet. & 4.2 & - & - \\
\hline Homoptera indet. & - & 6.1 & - \\
\hline Aphidodea & 2.1 & 9.2 & 2.8 \\
\hline Heteroptera indet. & - & - & 2.8 \\
\hline Pentatomidae & - & 1.5 & 2.8 \\
\hline Coleoptera indet. larvae & 6.4 & 4.6 & 11.1 \\
\hline Coleoptera indet. imagines & 10.6 & 10.8 & 5.6 \\
\hline Carabidae imagines & 2.1 & 3.1 & 5.6 \\
\hline Amara sp. imagines & - & 3.1 & - \\
\hline Anobiidae imago & 2.1 & - & - \\
\hline Chrysomelidae larva & - & 1.5 & - \\
\hline Curculionidae imagines & 4.2 & 3.1 & - \\
\hline Anthonomus sp. imago & - & 1.5 & - \\
\hline Hymenoptera indet. imago & - & 1.5 & $\overline{0.0}$ \\
\hline Symphyta: Tenthredinidae larvae & -19.1 & 4.6 & 8.3 \\
\hline Terebrantia indet. larva & - & 1.5 & $\overline{20}$ \\
\hline Terebrantia indet. imago & - & $\overline{1-5}$ & 2.8 \\
\hline Aphidiidae imago & - & 1.5 & - \\
\hline Aculeata imago & - & 1.5 & - \\
\hline Mecoptera: Panorpidae: Panorpa sp. larvae & 2.1 & 1.5 & 2.8 \\
\hline Lepidoptera larvae & 4.2 & 6.1 & 2.8 \\
\hline Diptera indet. larvae & - & 4.6 & - \\
\hline Diptera indet. pupa & - & 1.5 & - \\
\hline Diptera indet. imagines & 2.1 & 1.5 & 5.6 \\
\hline Nematocera indet. imagines & - & 3.1 & - \\
\hline Tipulidae larva & 一 & 1.5 & - \\
\hline Sciaridae larvae & - & 20.0 & 2.8 \\
\hline Cecidomyidae larva & 一. & 1.5 & - \\
\hline Brachycera indet. larva & - & 1.5 & - \\
\hline Brachycera indet. imagines & - & 1.5 & 2.8 \\
\hline Dolichopodidae imago & - & 1.5 & - \\
\hline Siphonaptera imago & - & 1.5 & - \\
\hline $\begin{array}{l}\text { Vertebrata (feathers, skin, muscle } \\
\text { and fatty tissue) }\end{array}$ & - & 4.6 & - \\
\hline
\end{tabular}

in the urban area $(84.0 \%)$, neither of the two urban areas studied differing in this respect (Table 1). Relatively small differences occurred in the volume percentage of this food fraction in its total volume in the Acta theriol., 3 
different study areas (Table 3), the proportion of animal food in the rodents' stomachs decreasing slightly with increase in urban pressure. Although the differences discussed above are statistically non-significant (Student $t$ test, $P_{0.05}$ ) it would appear to indicate that a tendency to more frequent consumption of animal food occurs in urban mice, with simultaneous decrease in its amount.

At Białolęka the young individuals more often consumed animal food than old individuals, whereas the opposite was the case in the city (differences statistically significant) (Table 1). An analogical tendency was also evident in respect of the volume of food consumed by the two age groups. At Białołęka this difference was relatively small (young individuals $12.9 \%$, old individuals $11.0 \%$ ), but in Eazienki Park the old individuals consumed twice as much animal food. In the Orthodox Cemetery both old and young individuals consumed identical amounts of animal food (each group $9.4 \%$ ).

Table 3

Percentage of stomach contents filled with the fraction examined.

\begin{tabular}{|c|c|c|c|c|}
\hline 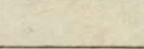 & Spring & Autumn & Winter & Whole year \\
\hline \multicolumn{5}{|c|}{ Białołęka } \\
\hline Females & 8.9 & $19.7^{2}$ & - & 14.5 \\
\hline Males & 12.3 & $7.9^{2}$ & - & 9.8 \\
\hline Total & 10.7 & 12.8 & - & 11.9 \\
\hline \multicolumn{5}{|c|}{ Orthodox Cemetery } \\
\hline Females & 11.9 & 7.3 & 7.7 & 8.2 \\
\hline Males & 9.0 & 9.8 & 11.9 & 10.8 \\
\hline Total & 10.4 & 8.3 & 10.0 & 9.5 \\
\hline \multicolumn{5}{|c|}{ Łazienki Park } \\
\hline Females & $6.6^{1}$ & 3.3 & 1.9 & $4.0^{3}$ \\
\hline Males & $18.7^{1}$ & 7.3 & 2.2 & $12.2^{3}$ \\
\hline Total & $14.7^{4,5}$ & $5.2^{4}$ & $2.1^{5}$ & 8.6 \\
\hline
\end{tabular}

${ }^{1} \ldots{ }^{5}$ Differences statistically significant (Student $t$ test, $p \leqslant 0.05$ ) when compared in pairs 11,22 , etc.

No significant differences were found in the proportion of stomachs containing animal food in individuals of the two sexes. The effect of urban conditions was, however, evident in the amount of food consumed by rodents (Table 3). It was only in Eazienki Park that the volume of animal food was different in individuals of the two sexes. The volume of this food fraction was almost three times greater in the stomachs of males than in those of females, nevertheless, when comparing the ratio of animal food over the course of a year in females and males, a distinct decrease was found in these proportions in a direction from Białołęka to the city (1.48 - Białołęka, 0.76 - Cemetery, 0.33 - Łazienki). 
On account of the lack of material from the winter period at Białołęka it was unfortunately impossible to make a complete analysis of the effect of urban pressure on the way in which Apodemus agrarius consumed animal food, but even so the results obtained show that under conditions of intensified urban pressure (Eazienki) the mice consumed more animal food in spring, and least in winter (Table 3). Thus while the proportion of this food was equal at all times of the year at Białokęka and in the Orthodox Cemetery, it exhibited a distinct decrease in autumn (about three times less) in Łazienki Park and an even more distinct decrease in winter (about seven times less). The decrease in this percentage is proportionately very similar in individuals of the two sexes (Table 3), although males consumed more animal food than females at all times of the year. The greatest (statistically significant) difference occurred in spring, and the smallest in winter. In the Łazienki Park males consumed far more in spring (from 50-100\%) of animal food than in the other study areas. At Białołęka there was a significant predominance of females during the autumn period in this respect, and during this period the proportion of animal food consumed by females was simultaneously far greater than in spring (more than twice as much).

\subsection{Differentiation of Food}

Animal food consumed by Apodemus agrarius consists chiefly of invertebrates, while vertebrates (fatty tissue, skin, muscles, feathers, fur) formed $4 \%$ of frequency.

Both at Białołęka and in the Łazienki Park a similar number of taxonomic groups of different rank are included in the composition of animal food (respectively 18 and 19), whereas in the Orthodox Cemetery the number is more than twice greater - 41 (Table 2). In the first two of these areas the majority of Diptera taxons and several others, such as Orthoptera, Blattodea, Acarina etc. were absent. Greater differences in the diet of mice from the Orthodox Cemetery may be partly due to the greater number of stomachs originating from this area (Table 1), although the possibility that the mice living in this area prefer Diptera cannot be ruled out.

In the majority $(68.9 \%)$ of the stomachs examined there were invertebrates belonging to one taxonomic group only (Table 4). Animals belonging to two groups were found in $20.3 \%$ of the stomachs, and up to three or more groups - in $10.8 \%$ of the stomachs. No important differences were found in this respect between different seasons of the year, or between females and males, but differences were found between 
the study areas. In suburbium the percentage of rodent stomachs containing one group was significantly higher than in the two urban areas. The percentage of stomachs with two systematic groups of invertebrates was significantly lower at Białołęka than in Łazienki Park.

In all the study areas (and particularly in Łazienki Park) the greatest percentage occurrence was found for insects (Fig. 2). The percentage occurrence of Aranea and Chilopoda was far lower, and that of the remaining groups minimal. Among Insecta the dominating group consisted in all areas of caterpillars (Lepidoptera and Hymenoptera Symphyta larvae), then imagines of Coleoptera and Diptera larvae (particularly Sciaridae) and Hemiptera imagines and larvae (Fig. 2). Insects belonging to other taxonomic groups were only sporadically consumed

Table 4

Percentage frequency of Apodemus agrarius stomachs containing a different number of taxonomic groups of invertebrates.

\begin{tabular}{ccccc}
\hline $\begin{array}{c}\text { Number of } \\
\text { taxonomic } \\
\text { groups }\end{array}$ & Białolęka & $\begin{array}{c}\text { Orthodox } \\
\text { Cemetery }\end{array}$ & $\begin{array}{c}\text { Łazienki } \\
\text { Park }\end{array}$ & $\begin{array}{c}\text { Whole } \\
\text { agglome- } \\
\text { ration }\end{array}$ \\
\hline 1 & $80.8^{1}$ & $60.0^{1}$ & 69.4 & 68.9 \\
2 & $12.8^{2}$ & 21.5 & $27.8^{2}$ & 20.3 \\
$>2$ & $6.4^{2}$ & 18.5 & $2.8^{2}$ & 10.8 \\
\hline
\end{tabular}

Statistically significant differences indicated in the same way as in Table 3 .

by mice. The percentage occurrence of the above groups of insects was, however, despite certain similarities, different in different study areas. Beetles were far more numerously represented in the diet of mice living in suburban areas than in the diet of urban mice, where their place was taken chiefly by Diptera larvae. The percentage frequency of caterpillars also decreased in the diet of rodents in the Orthodox Cemetery in comparison with the two other study areas, and also in favour of Diptera larvae. The percentage frequency of all larval forms thus varied, increasing from $50.2 \%$ at Białołęka to $59.5 \%$ in the Łazienki Park (differences on the verge of significance) (Fig. 2).

The percentage frequencies of the chief groups of invertebrates found in the stomachs of A. agrarius, calculated as the percentage of the number of specimens belonging to a given group out of the total number of specimens, presented a different picture (Fig. 3). In suburbium these percentages were more or less balanced, while one group predominated in the city. In the Orthodox Cemetery this group was formed by Diptera larvae (chiefly Sciaridae), while in Łazienki Park it consisted of caterpillars (Lepidoptera, Hymenoptera Symphyta). The proportions between the groups did not vary to any important degree at different 
seasons of the year, except that the percentage of Coleoptera decreased to almost twice lower a value in autumn in the city in comparison with spring, and beetles were not consumed in winter. The percentage of the dominating group (Diptera or Lepidoptera and Hymenoptera Symphyta larvae) increased proportionately (Fig. 3).

Statistically significant differences in the percentage of the chief systematic groups between the diet of females and males were found
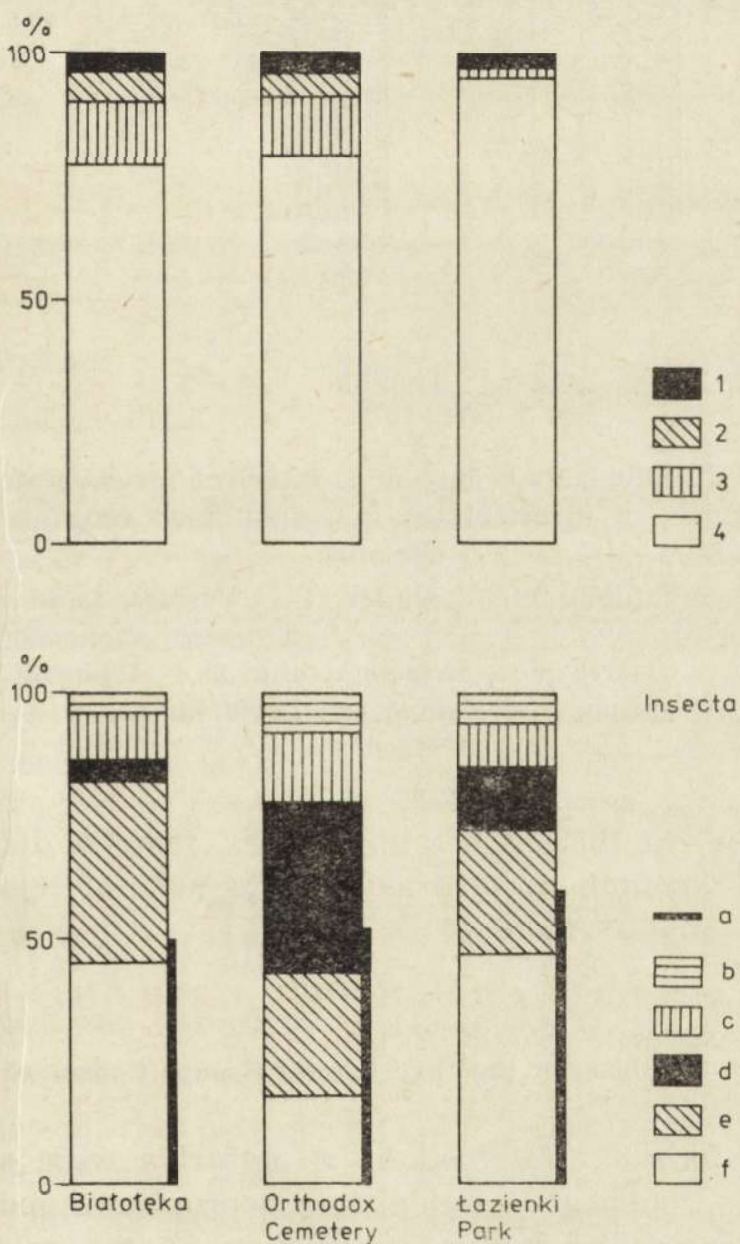

Fig. 2. Percentage occurrence $[(f / \Sigma f) 100]$ of different groups of invertebrates in food of animal origin consumed by Apodemus agrarius.

1 - Vermes, Lumbricidae, Mollusca, Acarina; 2 - Chilopoda; 3 - Aranea; 4 Insecta: a - proportion of larval forms; b - Blattodea, Orthoptera, Hymenoptera Terebrantia, Hymenoptera Aculeata, Mecoptera, Siphonaptera; c - Homoptera, Heteroptera; d - Diptera; e - Coleoptera; f - caterpillars (Hymenoptera Symphyta, Lepidoptera). 

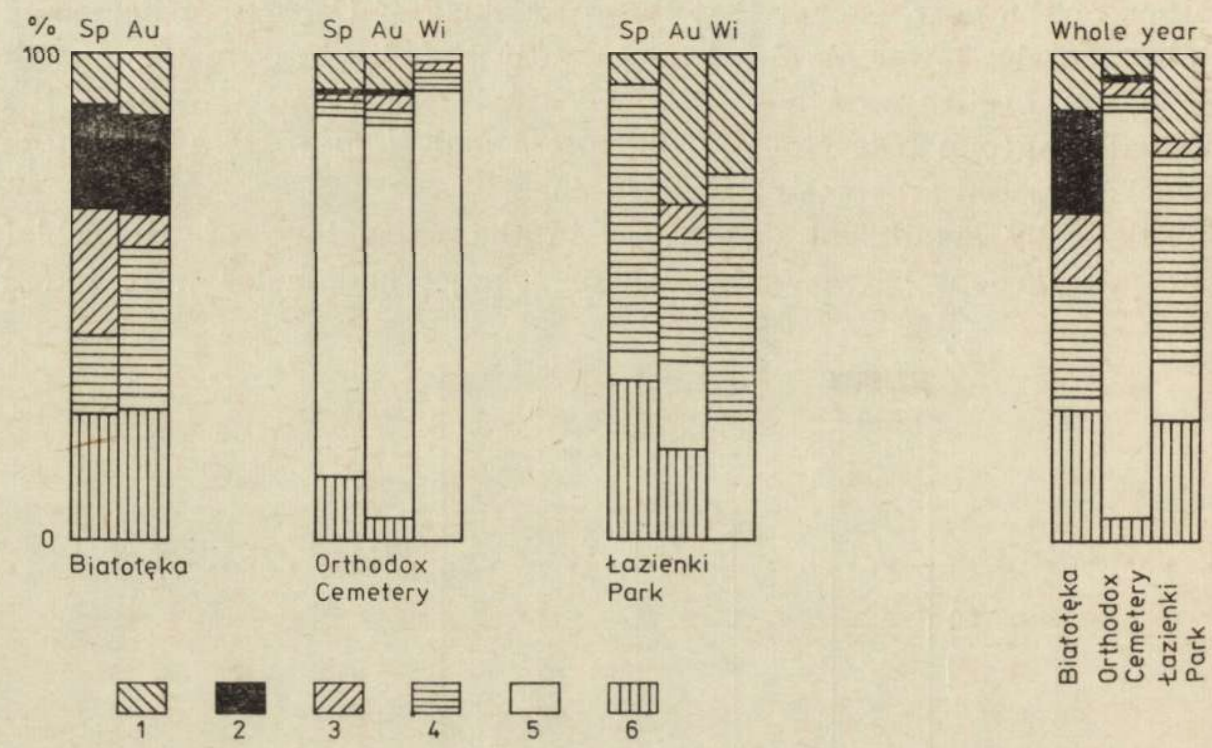

$\frac{\mathrm{WI}}{6}$

Fig. 3. Share $(\%)$ of individuals belonging to different invertebrate groups in total number of individuals of invertebrates in animal food consumed by Apodemus agrarius.

Sp - spring; Au - autumn; Wi - winter; 1 - Vermes, Lumbricidae, Mollusca, Acarina, Blattodea, Orthoptera, Homoptera, Heteroptera, Hymenoptera Terebrantia, Hymenoptera Aculeata, Mecoptera, Siphonaptera; 2 - Chilopoda; 3 - Aranea; 4 - caterpillars (Hymenoptera Symphyta, Lepidoptera); 5 - Diptera; 6 Coleoptera.

only at Białołęka. In this area, unlike males, females did not consume Diptera, while Coleoptera formed as much as $50 \%$ of their animal food (about $23 \%$ of males' food).

\subsection{Trophism of the Invertebrate Groups Consumed}

Invertebrates forming the food of $A$. agrarius were allocated to 4 trophic levels, i.e. zoophages, phytophages, saprophages and pantophages. Phytophages formed the highest proportion of the mice's diet, this including chiefly exophytophages (Table 5). Predators also formed a fairly high percentage, sometimes as much as $50 \%$. The lowest percentage was found for pantophages, which is to a certain extent understandable, since animals belonging to this trophic group form only a small percentage of the total number of species occurring in the Polish climatic zone. The percentage of phytophages increased in a direction towards the 
city centre, while that of predators decreased significantly. The fact appears interesting that in suburbium saprophages were not included in the composition of the mice's food, although in the city (and particularly in the Orthodox Cemetery) they constituted an important component (Table 5).

At Białołęka and in the Orthodox Cemetery the highest proportion of phytophages in the diet of Apodemus agrarius was found in autumn and lowest in spring. In Łazienki Park, however, phytophages formed the highest percentage in the mice's food, particularly in spring, and lowest in winter. It must be emphasized that whereas in suburbium the

Table 5

Percentage occurrence of different trophic groups of invertebrates in the stomachs of Apodemus agrarius.

\begin{tabular}{|c|c|c|c|c|c|c|}
\hline & \multirow[b]{2}{*}{ Zoophages } & \multirow{2}{*}{$\begin{array}{l}\text { Phyto- } \\
\text { phages }\end{array}$} & \multicolumn{2}{|c|}{ Phytophages } & \multirow{2}{*}{$\begin{array}{l}\text { Sapro- } \\
\text { phages }\end{array}$} & \multirow{2}{*}{$\begin{array}{l}\text { Panto- } \\
\text { phages }\end{array}$} \\
\hline & & & $\begin{array}{l}\text { Exophyto- } \\
\text { phages }\end{array}$ & $\begin{array}{c}\text { Piercing } \\
\text { phytophages }\end{array}$ & & \\
\hline
\end{tabular}

\section{Białołęka}

Spring

Autumn

\section{$50.0^{1}$}

$22.4^{1}$

$34.4^{2}$

\section{$41.7^{4}$}

$71.6^{4}$

$62.3^{5}$

\section{0}

85.4

$84.2^{9}$

20.0
14.6

14.6

15.8

$\begin{array}{ll}- & 8.3 \\ - & 6.0\end{array}$

Orthodox Cemetery

Spring 33

Autumn 33.3

Winter

$$
25.7
$$

27.3

Whole year

$33.3^{6}$

$48.6^{6}$

45.4

100.0

41.2

100.0

$64.4^{9}$

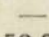

58.8

35.5

22.9

27.3

22.3

$14.5^{10}$

$43.7^{7}$

$\begin{array}{lr}85.2^{8} & 100.0 \\ 69.2 & 74.2 \\ 66.6^{8} & 100.0 \\ 79.7^{5,7} & 84.5\end{array}$

$\overline{25.8}$

14.5

14.5

10.2

$33.3^{3}$

Whole year $\quad 11.6^{2}$

84.5

4.3

Statistically significant differences indicated in the same way as in Table 3 .

proportion between the percentages of exophytophages and piercing phytophages remain on a similar level at all times of the year, in the city piercing phytophages were consumed solely in autumn, and exophytophages only in spring and winter. The proportions of zoophages were highest in spring at Białołęa and in the Orthodox Cemetery, but in the Łazienki Park in winter, although they were lowest, as in the other two areas, in autumn (Table 5). All these differences were statistically significant when checked up by Student $t$ tests.

In the Orthodox Cemetery the percentage of saprophages in the diet of A. agrarius was similar at all seasons of the year; in Łazienki Park 
invertebrates belonging to this trophic level were included in the composition of the rodent's food only in autumn, as was the case with pantophages. In the other two study areas, on the other hand, the percentage of this group was highest in spring.

No statistically significant differences were found in the degree of exploitation by male and female mice of the trophic levels of prey distinguished, with the exception of the Eazienki Park, in which phytophages were consumed solely by females, and sapro- and pantophages by males.

\subsection{The Living Spaces of Prey}

Four biocentric layers were distinguished (soil, litter, epigeon, vegetation) forming the living spaces of invertebrates included in the composition of the food of $A$. agrarius.

The highest percentage for all the study areas in the diet of Apodemus agrarius was formed by invertebrates living on plants (Table 6), probably chiefly living in the herb layer. The proportion of animals inhabiting the soil, relatively high in the Orthodox Cemetery, was significantly lower in the Łazienki Park. At Białołęka this group was not represented in the rodents' food, but a considerable part of this food consisted of invertebrates connected with the litter layer, the percentage of which was very small in the diet of urban populations (statistically significant differences). The percentage of epigeic animals in all the study areas was also remarkable (Table 6).

At Białołęka and in the Orthodox Cemetery invertebrates living on plants were most readily consumed by the mice in autumn, and least readily in spring. The reverse situation was observed in Łazienki Park, in which area the percentage of invertebrates living on plants was highest in the $\operatorname{diet}$ of $A$. agrarius in winter, but lowest in autumn. In spring a relatively considerable part of the food of urban mice consisted of epigeic animals, which were absent at this time of the year in the food of the populations living in suburbium, whereas an important part was played by invertebrates connected with the litter layer. It was only in Eazienki Park that a distinct connection was observed between the rodents' search for food in given layers and the season of the year: in winter only those invertebrates living on plants were consumed, in spring in addition to the foregoing animals epigeic animals, but in autumn only the rodents' food also included animals living in litter and soil (but no epigeic animals).

All the layers distinguished were penetrated to a similar degree by 
Table 6

Biocenotic layer classification of invertebrates found in the stomachs of Apodemus agrarius (percentage occurrence).
Soil
Litter
Epigeon
Living on plants

Białołęka

$\begin{array}{lllll}\text { Spring } & - & 42.8 & - & 57.1^{4} \\ \text { Autumn } & - & 12.7 & 7.3 & 80.0^{4} \\ \text { Whole year } & - & 23.4^{2,3} & 4.2 & 72.3\end{array}$

Orthodox Cemetery

Spring

Autumn

Winter

Whole year

25.0

30.8

30.0

$28.7^{1}$

Łazienki Park

Spring

Autumn

Winter

Whole year

5.8
3.8
-

$3.7^{2}$

\begin{tabular}{ll}
25.0 & $44.2^{5}$ \\
$\overline{10.0}$ & $65.4^{5}$ \\
10.0 & 60.0 \\
\hline & 57.5
\end{tabular}

Statistically significant differences indicated in the same way as in Table 3 .

both males and females of Apodemus agrarius. It was only in Łazienki Park that the females consumed, in addition to invertebrates living on plants, epigeic animals only, while the males also consumed animals inhabiting the soil and litter.

\section{DISCUSSION}

The effect of urban pressure causes two opposite tendencies to occur: on the one hand frequency of consumption of animal food increases (higher percentage of the $A$. agrarius population consumed this type of food), while on the other hand its volume decreased. This state of affairs was not due to the smaller numbers of invertebrate fauna in the city, since both in Łazienki Park and at Białołęka these numbers were similar. There were, however, differences in the proportions of the different taxonomic groups of invertebrates in their total numbers (data from the Institute of Zoology, Polish Academy of Sciences). In Łazienki Park Formicoidea decidedly predominated among the epigeic fauna, and among invertebrates living on plants, Hemiptera, neither of these groups being readily consumed by the mice. Diplopoda, which these mice also 
refrained from consuming, were also numerous in Łazienki Park. Groups readily consumed by $A$. agrarius (larvae of Lepidoptera and Hymenoptera Symphyta, imagines of Coleoptera, Aranea), on the other hand, were far less numerous in Łazienki Park than at Białołęka. One of the reasons for lower consumption of animal food in the city might thus have been the predominance of unsuitable invertebrates, and a deficiency of the invertebrate groups preferred by the mice. A second reason may have been the abundance of seeds (particularly of trees) which form the basic food of Apodemus agrarius (Holišova, 1967; Babińska-Werka, 1981). This would explain the low proportion of animal food in autumn and winter, when there is an abundant supply of seeds, and the high proportion in spring when such supplies (particularly after spring cleaning operations in the park) are coming to an end. The decrease in the percentage of invertebrates in the diet of mice in the autumn and winter may also be due to another cause. In such a carefully tended park as Łazienki Park the fallen leaves and dead parts of the herb layer are raked up and removed in autumn, which makes it impossible for many invertebrates to live through the winter, particularly insects (Segebade \& Schaefer 1969) and their numbers are thus of necessity reduced. This brings about a decrease in the proportion they form in the rodents' diet at these times of the year, and consequently also in the yearly average.

The fact that old, sexually active individuals consumed more animal food than young individuals can be explained in two ways. In the first place old individuals may be more capable of finding this type of food, their skill having been acquired by experience. The more extensive home ranges of old individuals may also be of significance. In addition sexually active individuals have greater requirements for high-calorie animal food, that is, for protein and fatty food (Kaczmarski, 1966; Migula, 1969). Greater food consumption of sexually active mice was also observed by Holišova (1967). It would be more difficult to explain why the reverse tendency was found at Białołęka.

The greater percentage of invertebrates in the diet of males may be due to their greater activity. It is also known (Sahno, 1957) that animal food intensifies the process of spermatogenesis: this may be the reason for the increased requirements of males for this kind of food. All these hypotheses, although logical, cannot be applied to the rodents' diet at Białołęka, since in suburbium the males consumed less animal food than females. It is unfortunately somewhat difficult to find an explanation for this phenomenon. If, however, the fact is taken into consideration that differences in the proportion of animal food in individuals of both sexes resulted chiefly from the decrease in this proportion in the diet of females of the urban populations (the proportion of invertebrates in 
the diet of males even increased slightly in a direction towards the city), it may be concluded that in the city females, for some unknown reasons, have smaller opportunities of consuming animal food than males.

From the aspect of the variety of food consumed by the mice it is possible to discern two, apparently opposite, tendencies. The stomach of the average urban mouse contained more diversified food than that of a mouse living in suburbium, while at the same time the percentages of different groups of invertebrates in their food as a whole was more balenced at Białołęka. This is certainly due to differences in the degree of the mosaic character of the study areas. In the city the habitat is undoubtedly more uniform, hence different groups of animals are more or less equally accessible to the mice. In suburbium, however, where the area is more diversified, the probability of the rodents' coming across a concentration of invertebrates belonging to one given taxonomic group (even single species) is greater. Hence usually only one group was found in the stomachs of mice from Białolęka. As, however, the home ranges randomly include different parts of the study area (occupy different microhabitats) different individuals encountered varying groups of invertebrates. Consequently the proportions of the chief groups of invertebrates were balanced in the food of the whole study population. The establishment of this fact may form a basis for the hypothesis that the field mouse does not exhibit definite food preferences. This same conclusion was reached by Holišová (1967). The results obtained from examination of the food of urban populations, however, contradict this conclusion, since it was chiefly invertebrates belonging to one taxonomic group which predominated in the diet of mice living in the city. In Eazienki Park these were caterpillars (Lepidoptera and Hymenoptera Symphyta larvae) the numbers of which, as compared with other invertebrates, were relatively low in this area. Several groups of dominating animals were not, however, as already mentioned, included in the composition of their food. It must therefore be concluded that these mice selectively search for food, preferring certain kinds of animal food and avoiding others. These preferences may be due to different causes. One of them is undoubtedly the availability of the prey, not only in the sense of its abundance but also ease of search and capture. In this sense phytophages are most easily accessible, particularly Lepidoptera and Symphyta larvae. They are fairly large and thus usually easy to descry and not very active, that is, are easily caught. Orthoptera and Hemiptera (majority) and also the imagines of many orders of Insecta, such as Diptera, Lepidoptera and Hymenoptera possess far greater ability to escape, hence they are either absent from or appear in very small proportions in the rodents' diet. The body dimensions of representatives of 
certain other groups (Aphidodea, Acarina), on the other hand, are too small to make them objects of purpuseful search by the mice. They are most probably consumed together with the plants on which, or inside which (Cecidomyidae), they are present and thus consumed entirely fortuitously. Obrtel (1972) reached exactly the same conclusion during studies on the food of Apodemus flavicollis. Ants are not consumed, probably on account of their unpleasant taste (formic acid); neither are Diplopoda, on account of their low fat and proteins content (Obrtel, 1972).

The relatively high percentage formed by Coleoptera imagines in the rodents' food is most probably due to the ease with which they can be caught, as insects not capable of effective flight, and also on account of their tendency to congregate (for purposes of laying eggs, aestivation, food consumption). It is also probably due to their considerable abundance, and this latter factor may also account for the high percentage of spiders in the diet of Apodemus agrarius.

The percentages of different groups of invertebrates observed in these studies, differ slightly from the results obtained by Holišova (1967), for instance Lumbricidae and Collembola were not found in the rodents' food, and the frequency of vertebrate and Homoptera remains was lower, even though they occurred in the study areas.

Saprophages, as animals living mainly in the soil, are less accessible, hence their percentage is generally smaller. Among them those groups predominate which exhibit a tendency to congregate (Sciaridae) and to emerge on to the soil surface (also Sciaridae and Mecoptera). The absence of this group at Białołęka may have been due to the fact that the litter layer is far thicker (2-3 times thicker) that in the Eazienki Park, which presumably makes it more difficult for the mice to reach the soil. Intensity of penetration of the litter layer itself, however, increases.

Consumption of saprophages by Apodemus agrarius may in certain cases exert an unfavourable effect on biocenosis function by delaying the rate of the mineralization process of organic matter. A negative phenomenon is also consumption of zoophages, which in consequence may lead to reduction in the self-regulating capacity of the ecosystem. If, however, the fact is taken into account that the dominating group in the animal components of the field mouse's food usually consists of phytophages (particularly such serious pests as Lepidoptera and Symphyta larvae) it must be considered that this species, as a predator, plays a beneficial role in the urbicenosis from the aspect of plant protection, and is thus a valuable element of the fauna of urban green areas.

Acknowledgements: We should like to express our sincere gratitude to all the specialists from the Institute of Zoology, Polish Academy of Sciences, who gave us assistance with identification of material, in particular B. Burakowski (Ano- 
biidae), K. Cholewicka (Curculionidae), W. Czechowski (Carabidae), W. Jędryczkowski (Chilopoda), E. Krzyżanowska (Aranea) and W. Mikołajczyk (Nematocera).

\section{REFERENCES}

1. Babińska-Werka J., 1981: Food of the striped field mouse in different types of urban green areas. Acta theriol., 26: 275-283.

2 Holišová V., 1967: The food of Apodemus agrarius (Pall.). Zool. Listy, 16: 1-14.

3. Kaczmarski F., 1966: Bioenergetics of pregnancy and lactation in the bank vole. Acta theriol., 11: $409-417$.

4. Landry S. O., Jr., 1970: The Rodentia as omnivores. Quart. Rev. Biol., 45: $351-372$.

5. Migula P., 1969: Bioenergetics of pregnancy and lactation in European common vole. Acta theriol., 13: 167-179.

6. Obrtel R., 1973: Animal food of Apodemus flavicollis in a lowland forest. Zool. Listy, 22: $15-30$.

7. Sahno I. I., 1957: Materiały k izučeniju sostava kormov nekotoryh myševidnyh gryzunov. Zool. Ż., 36: 1084-1092.

8. Segebade R. \& Schaefer M., 1979: Zur Oekologie der Arthropodenfauna einer Stadtlandschaft und ihrer Umgebung. II. Pflanzengallen und Pflanzenminen. Anz. Schädlingskde., Pflanzenschutz, Umweltschutz, 52: 117-121.

9. Sviridenko P. A., 1944: Rasprostranienie, pitanie i epidemiologičeskoje značenie polevoj myši. Dokł. AN SSSR, 42: 96-100.

Accepted, April 22, 1981.

Joanna BABIŃSKA-WERKA i Henryk GARBARCZYK

\section{POKARM POCHODZENIA ZWIERZECEGO W DIECIE MYSZY POLNEJ ŻYJACEJ W WARUNKACH MIEJSKICH}

\section{Streszczenie}

W latach 1977-1979 przeprowadzono analizę pokarmu pochodzenia zwierzęcego inyszy polne, Apodemus agrarius (Pallas, 1771), żyjącej w suburbium (Białolęka Dworska) i na dwóch terenach zieleni miejskiej Warszawy (Cmentarz Prawosławny i Park Łazienki). Łącznie zbadano zawartość 187 żołądków (Tabela 1) stosując zmodyfikowaną metodę Holišovéj $(1966,1971)$. Szczątki zwierzęce, znajdujące się przeważnie $\mathrm{w}$ stanie bardzo rozdrobnionym, oznaczono $\mathrm{z}$ reguły do wyższych jednostek taksomicznych (Tabela 2).

W warunkach miejskich ilość i jakość pokarmu zwierzęcego w diecie myszy uległa zmianie: zwiększyła się częstotliwość konsumowania tego typu pokarmu, a jeđdnocześnie jego objętość w żołądkach malała (Tabela 1 i 3). Myszy zjadały głównie bezkręgowce, podczas gdy kręgowce stanowiły tylko $4 \%$ frekwencji (Tabela 2). Wszystkie znalezione szczątki zwierzęce zaklasyfikowano do 47 grup systematy/cznych (różnej rangi). W większości żołądków (69\%) stwierdzono bezkręgowce nalez̈ące do jednej tylko grupy (Tabela 4). Wśród pokarmu zwierzęcego przewa- 
żały Insecta, a w mniejszym stopniu Aranea i Chilopoda. Na wszystkich terenach badań dominowały wśród owadów gąsienice (larwy Hymenoptera Symphyta i Lepidoptera), następnie imagines Coleoptera i larwy Diptera (zwłaszcza Sciaridae) oraz imagines i larwy Hemiptera (Ryc. 2). Myszy z terenów miejskich wyraźnie preferowały określone grupy owadów, podczas gdy w diecie myszy żyjącej w suburbium udział poszczególnych grup był bardziej wyrównany (Ryc. 3). Udział form larwalnych owadów w pokarmie myszy z terenów miejskich był wyższy niż u myszy w suburbium (Ryc. 2). W mieście najwyższy udział w diecie A. agrarius miały fitofagi (głównie zgryzające), znacznie mniejszy zoofagi, natomiast pantofagi spotykane były tylko sporadycznie (Tabela 5). Oprócz bezkręgowców naroślinnych, które dominowały w pokarmie myszy na wszystkich terenach badań, w mieście, w porównaniu z suburbium, myszy zjadały więcej zwierząt zamieszkujących glebę, natomiast mniej bezkręgowców związanych z warstwą ściółki (Tabela 6).

W dyskusji omawiana jest rola, jaką pełni Apodemus agrarius na terenach zieieni miejskiej z punktu widzenia jej zwyczajów pokarmowych. 